\title{
ENTOMOLOGY
}

\section{Effects of various sugar feeding choices on survival and tolerance of honey bee workers to low temperatures}

\author{
H.F. Abou-Shaara \\ Department of Plant Protection, Faculty of Agriculture, Damanhour University, Egypt
}

\begin{abstract}
Beekeepers usually supply their colonies with alternatives to nectar (i.e. sugar feeding) during dearth periods of the year, especially cold times of winter. The objective of the study was to determine the best substances to feed bees to enhance the tolerance and survival of honey bees (Apis mellifera L.) to low temperatures. Seven feeding choices were compared under laboratory conditions. These feeding choices were: sugar syrup, liquid honey, creamed honey, honey candy, sugar candy, honey jelly, and honey/sugarcane juice jelly. The results showed that the number of bees attracted to each feeding choice was influenced significantly by feeding type. Worker bees were attracted to all feeding choices and showed a high preference to creamed honey, honey jelly or honey/juice jelly. The tolerance of honey bees to low temperature was enhanced when bees were fed on creamed honey, sugar syrup or honey candy. The mean time at which $50 \%$ of bees were able to survive ranged from 3 days (unfed bees) to 15.8 days (honey candy group). The survival rate of worker bees was highest when they fed on honey candy, creamed honey or sugar candy. In light
\end{abstract}

Correspondence: Hossam F. Abou-Shaara, Department of Plant Protection, Faculty of Agriculture, Damanhour University, Damanhour, 22516, Egypt.

E-mail: hossam.farag@agr.dmu.edu.eg

Key words: honey bees; Apis mellifera; sugar; feeding; cold; tolerance.

Acknowledgments: I would like to thank Prof. Dr. Boris Kondratieff (Colorado State University, USA) for his careful reading of the manuscript and for his valuable comments.

Conflict of interest: the author declares no potential conflict of interest.

Received for publication: 25 July 2016

Revision received: 7 November 2016.

Accepted for publication: 3 Janaury 2017.

CCopyright H.F. Abou-Shaara, 2017

Licensee PAGEPress, Italy

Journal of Entomological and Acarological Research 2017; 49:6200 doi:10.4081/jear.2017.6200

This article is distributed under the terms of the Creative Commons Attribution Noncommercial License (by-nc 4.0) which permits any noncommercial use, distribution, and reproduction in any medium, provided the original author(s) and source are credited. of this study, creamed honey or honey candy can be considered the best feeding choices for bee colonies during winter to enhance their survival and tolerance to low temperatures.

\section{Introduction}

Honey bee (Apis mellifera L.) colonies often have a large number of workers reaching 15,000 to 60,000 bees (Southwick \& Heldmaier, 1987). Such large numbers of bees require a large amount of food to sustain their survival and development. Sufficient nutrition can boost the development of healthy bee colonies (Brodschneider \& Crailsheim, 2010). Nectar, mainly as a source of carbohydrates, is needed in large amounts by honey bee colonies. Nectar is very important to honey bee workers as a source of energy especially during winter where worker bees engage in strategies to keep the brood temperature within a suitable range from 33 to $36^{\circ} \mathrm{C}$ for colony survival, including warming of the brood caps superficially, or internally by heating bees (Kleinhenz et al., 2003). During winter, high colony weight loss was reported by Seeley \& Visscher (1985) as an indication of high honey consumption during this critical period of the year. Low temperature during winter has been considered as a cause of honey bee colony losses in some Arabian countries (Al-Ghamdi et al., 2016). High colony losses have been reported in regions with low mean temperatures in the USA (van Engelsdorp et al., 2008). Colony losses generally occur during winter. Such losses have been estimated to be $19 \%$ in Belgium during 2009/08 (Nguyen et al., 2010) and 22.5\% in the USA during 2011/12 (Spleen et al., 2013). Starvation has been considered as one reason behind colony losses from $6.0 \%$ to $17.8 \%$ during winter in Austria (Brodschneider et al., 2010). The winter colony losses in Germany were reported to be $3.8 \%$ to $15.2 \%$ in $2004 / 05$ and 2005/06 (Genersch et al., 2010). Bee colonies suffer greatly from shortage of nectar sources as well as unsuitable conditions for foraging during winter. Thus, beekeepers need to supply colonies with alternatives to nectar. It is commonly known that the best alternative to nectar is pure sucrose (Barker, 1977), but, searching for more cost-effective alternatives with adequate nutritional value to honey bees is needed.

Some feeding, such as heated or old honey is less suitable to bees while acid-hydrolysed carbohydrates can be toxic to bees (Bailey, 1966). There was no reported advantage of feeding high fructose corn syrup or honey over sucrose syrup. Grape syrup, when fed to bees, shortened survival and caused dysentery (Barker \& Lehner, 1978). Under field conditions, brood development was increased in colonies fed on honey (Andelković et al., 2011). The 
problems of liquid honey are in its ability to spread disease among colonies and high viscosity. Abd El Hamid \& Abou-Shaara (2016) presented a simple method to produce creamed honey using powdered glucose and a refrigerator. These authors found produced creamed honey was attractive to honey bees and it was consumed within 24 hours. Using creamed honey (especially that made from low marketable honey choices) could be considered as a natural alternative to commercial sugars. Sugarcane juice is relatively inexpensive if compared with table sugar (sucrose). According to Carrillo et al. (2015), sugar syrup was better than sugarcane juice as energy source for beeswax production. The main problem with juice is rapid fermentation due to its high water content. Using juice in a solid form may solve this problem and make it more effective.

Winter bees can better survive cold conditions if provided with a suitable energy source (i.e. sugar feeding). The objective of the study is to test different feeding choices to enhance the ability of bees to survive under cold conditions (i.e. to boost their wintering ability). Two forms of feeding choices were tested; liquid and solid. The effects of feeding choices on the survival and tolerance of honey bees to cold conditions were tested.

\section{Materials and methods}

\section{Sugar feeding choices}

In this study, seven choices of feeding (suitable sources for winter feeding) were tested under laboratory conditions. Feeding choices included the following.

I) Sugar syrup: was made by mixing table sugar with water (2:1, $\mathrm{w} / \mathrm{w})$.

II) Liquid cotton honey: cotton honey is available to colonies during autumn. This type of honey was selected because it has low price, a source beekeepers can utilize to feed colonies.

III) Creamed cotton honey: it was produced by mixing $2.4 \%$ (w/w) powdered glucose to liquid cotton honey and stored on $4^{\circ} \mathrm{C}$ until full crystallization following Abd ElHamid \& AbouShaara (2016), except honey was not heated.

IV) Cotton honey jelly: it was produced by adding $10 \mathrm{~g}$ of gelatin dissolved in $100 \mathrm{~mL}$ of water to $200 \mathrm{~g}$ liquid honey. The mixture was heated for 1 minute in water bath. Pectin was not used as solidifying material because toxicity to honey bees (Barker, 1977).

V) Honey/sugarcane juice jelly (abbreviated as honey/juice jelly) was produced by adding $5 \mathrm{~g}$ of gelatin to a mixture of $100 \mathrm{~mL}$ sugarcane juice and $100 \mathrm{~g}$ of cotton honey in water bath for 1 minute. Feeding choices 4 and 5 were produced based on some preliminary experiments, but the mentioned amounts of gelatin, honey and juice were only found to be suitable for producing honey or honey/juice jelly. Also, preliminary studies showed that bees are able to absorb food from these choices of jelly.

VI) Honey candy was prepared by saturating honey with powdered sugar in a water bath.

VII) Sugar candy: water was saturated with powdered sugar ratio (4 sugar : 1 water, w/w) in water bath.

\section{Sampling and experimental cages}

Hybrids of Carniolan honey bee colonies from an apiary located at Damanhour City, Egypt were used. Honey bee workers of approximately foraging age (older than 21 days) were collected from the lateral combs of the colonies in small well ventilated plastic jars. The bees were starved at room temperature for 12 hours prior to each experiment (Wang et al., 2016). Then, the bees were placed in a freezer for 4 minutes to immobilize them prior to distribution into experimental cages. The number of worker bees varied according to the experiment. The experiments were performed during spring 2016. The experimental cages were constructed using petri dishes and small plastic sheets (Figure 1). The cage diameter was $8.5 \mathrm{~cm}$ by $5 \mathrm{~cm}$ deep. The bottoms of cages were provided with 4 tightly fixed Eppendorf tubes to be filled with water when necessary. According to Simpson (1964), dry sugar is diluted by bees more than concentrated syrup or honey and generally food containing less than $50 \%$ of sugar is not diluted by bees. Therefore, each cage was provided with a water source.

\section{Preference of honey bees to tested feeding choices (Experiment 1)}

Four cages were used in this experiment. In each cage, small amounts ( 0.5 grams) of all feeding choices were placed in small plastic plates. Ten bees were placed in each cage. The number of bees attracted to each feeding choice was counted after $3,6,9,12$, 15 minutes and after 1, 4, 8, and 12 hours after placing the bees into the cages. The number of bees attracted to each feeding choice was then compared to detect preference of honey bees to specific sugar feeding type.

\section{Tolerance to low temperature (Experiment 2)}

Per each feeding type, three cages equipped with $5 \mathrm{~g}$ of feeding type and $1.5 \mathrm{ml}$ of water were used in addition to three cages that were provided only with water. Ten bees were placed in each cage ( 3 cages $/ 30$ bees per treatment, total of 240 bees). The bees were allowed to feed on the feeding for 12 hours then the cages were placed in a refrigerator at $6 \pm 1^{\circ} \mathrm{C}$. The number of surviving bees (bees exhibiting movement) in each cage was recorded each minute. Then, number of surviving bees per each minute was compared. After all the bees in the cages of each treatment were motionless, the cages were placed at room temperature (at $19 \pm 1^{\circ} \mathrm{C}$ ). The time at

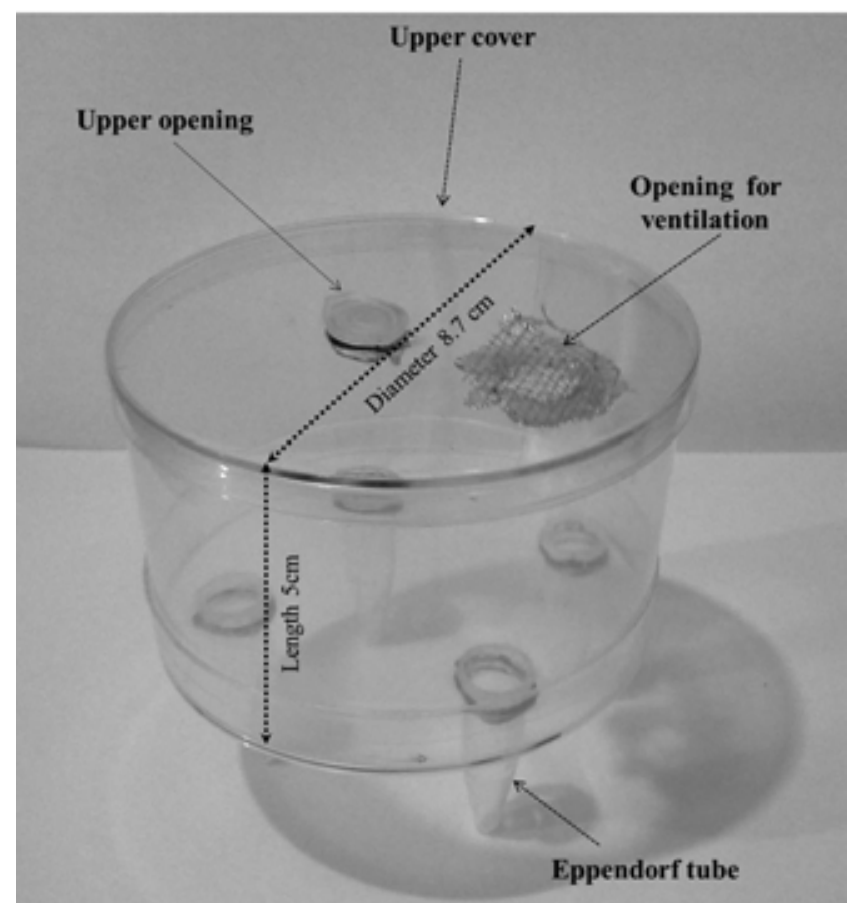

Figure 1. Description of cage parts used in the experiments. 
which the bees started to recover (showed whole-body movement) was recorded as well as the number of recovered bees after 10 and 15 minutes. The feeding type that caused highest survival rate was then identified. The consumption rate $(5-$ consumed amount / $5 \times 100)$ of each feeding type was also calculated.

\section{Survival of honey bees (Experiment 3)}

Three cages equipped with $10 \mathrm{~g}$ of feeding and supplied with $1.5 \mathrm{~mL}$ of water were used in this experiment per each feeding type beside three cages supplied only with water. 15 workers were placed in each cage ( 45 workers per treatment, total of 360 bees). Each cage was also provided with a piece of wax comb $(4 \times 3 \mathrm{~cm}$, $\mathrm{LxW}$ ). This wax piece was added to allow bees to stand on it. The cages were left at room temperature (at about $20 \pm 1^{\circ} \mathrm{C}$ ) during the experiment. The cages were inspected daily and the number of surviving bees was recorded until the death of all bees. The number of

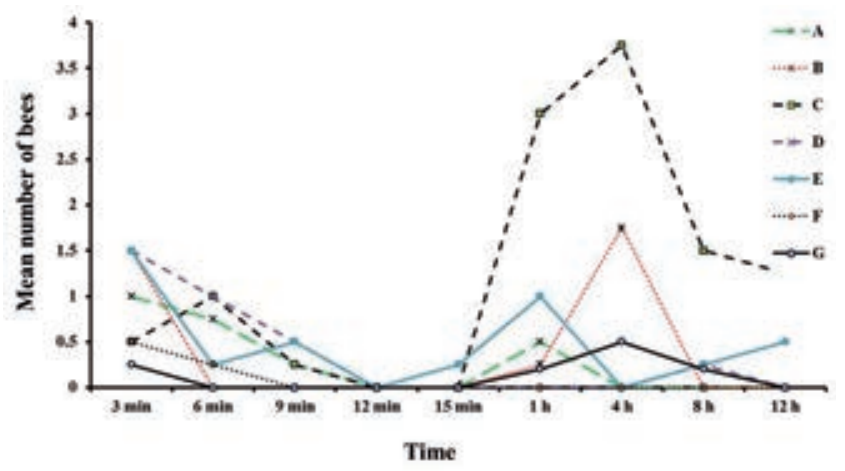

Figure 2. Mean number of bees per cage (= number of bees/4) per feeding type during the experiment. (A: Liquid honey, B: Honey jelly, C: Sugar candy, D: Honey/juice jelly, E: Creamed honey, F: Honey candy, G: Sugar syrup). surviving bees was compared among feeding choices to identify the best feeding choice with respect to enhancing survival ability of bees in cold air temperature conditions. The consumption rate $(10$ - consumed amount $/ 10 \times 100)$ of each feeding type was also calculated.

\section{Statistical analysis}

All the experiments were of complete random design (CRD). The independent factors for the first and second experiment were feeding choices and experimental time while, for the third experiment, only feeding choices was considered as an independent factor. Means and standard errors (S.E.) were calculated for each studied parameter. Then, one way or two-way ANOVA was performed, and means were then compared using Duncan's multiple range test $t_{0.05}$. Pearson correlation coefficient at $5 \%$ level of significance was also calculated to assess correlations between survival period and percent of consumed food. The SAS (Version 9.1.3, SAS Institute, $\mathrm{NC}, 2004)$ was used in the statistical analysis.

\section{Results \\ Preference of honey bees to specific feeding choice}

The number of bees attracted to each feeding type was influenced significantly by feeding choices $(\mathrm{P}=0.0001<0.05, \mathrm{~F}=8.88)$ as well as experimental time $(\mathrm{P}=0.0001<0.05, \mathrm{~F}=8.88)$. Also the interaction between feeding type and experimental time was significant $(\mathrm{P}=0.0001<0.05, \mathrm{~F}=8.88)$ as shown by the Two-factor ANOVA. After three minutes, bees attracted to all feeding choices but the highest number of bees were at honey jelly, honey/juice jelly, and creamed honey with no significant differences $(\mathrm{P}>0.05)$ as shown in Figure 2. The number of bees decreased at all feeding choices by time and stayed without feeding at 12 and 15 minutes (Figure 3). After one hour, the high number of bees attracted to sugar candy was significantly different $(\mathrm{P}<0.05)$ than all the other feeding choices with $\%$ of $30,37.5,15$, and 12.5 of the total ( 40 bees) at $1,4,8$ and 12 hours, respectively. At 12 hours, bees attracted only to sugar
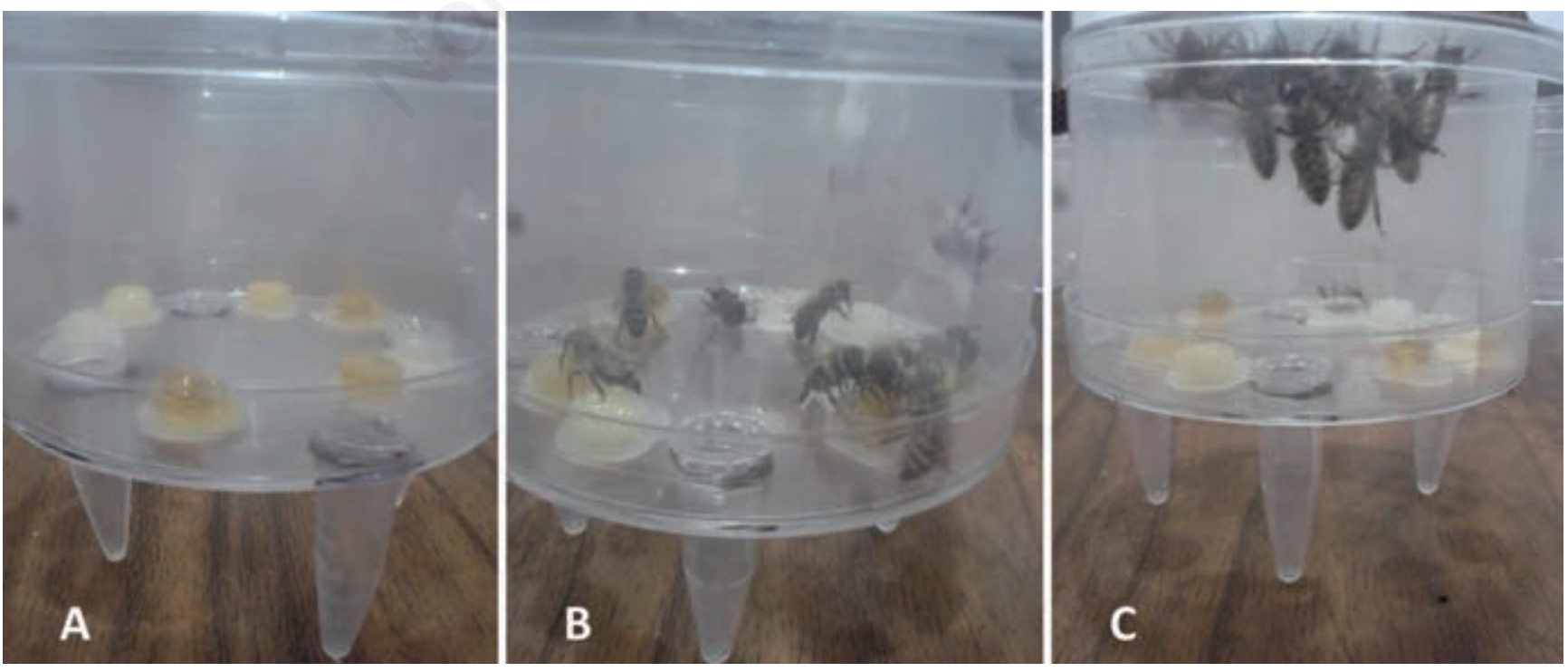

Figure 3. Preference experiment. A) Distribution of feeding plates within the cage, B) Bees during feeding, and C) Bees during non-feeding. 
candy and creamed honey. In the course of the experiment period, sugar candy differed significantly than the other feeding choices and had the highest mean with $1.25 \pm 0.30$ bees.

\section{Tolerance to low temperature}

As indicated in Table 1 , during the first 5 minutes at $6 \pm 1{ }^{\circ} \mathrm{C}$, bees of each feeding choice showed 100\% survival ability (apparent moving within cages), without significant differences among them. During the next 5 minutes, only bees fed on sugar syrup and honey/juice jelly showed $100 \%$ survival ability followed by workers fed on liquid honey, creamed honey, honey candy and sugar candy, respectively. These feeding choices differed significantly than workers fed on honey jelly and unfed bees. After 11 to 15 minutes, the highest survival was for workers fed on creamed honey and sugar syrup followed by liquid honey without significant differences among them. These feeding choices differed significantly than the other feeding choices. The lowest survival ability was recorded to unfed bees. During the last four minutes, no significant differences were found among surviving bees fed on honey candy, creamed honey, sugar syrup, honey/juice jelly, and sugar syrup while bees of all the other treatments stayed motionless. The correlation between survival ability and exposure time to low temperature was negative $(\mathrm{r}=-0.84, \mathrm{P}<0.0001)$.

As shown in Figure 4, it is apparent that bees were able to survive up to 19 minutes only when fed sugar syrup, creamed honey, and honey candy. Bees survived up to 18 minutes on sugar candy and honey/juice jelly, and up to 12, 15, and 16 minutes on no food, honey jelly, and liquid honey, respectively. From these experiments it is concluded that creamed honey, sugar syrup, and honey candy are the best feeding alternatives to enhance bee survival ability to cold air temperature conditions followed by honey/juice jelly and sugar candy.
The bees fed on all feeding choices were able to recover (whole body moving ability) within 2.05 minutes (Table 2). No significant differences were found between feeding choices with regard to recovery time but bees fed on sugar syrup showed slightly faster recovery (1.50 minutes). Unfed bees were slower in their recovery than fed individuals. After 10 and 15 minutes, no significant differences were found among bees fed on different feeding choices. Unfed bees had significantly less number of recovered bees than fed ones. The consumption \% ranged from 2.66 to

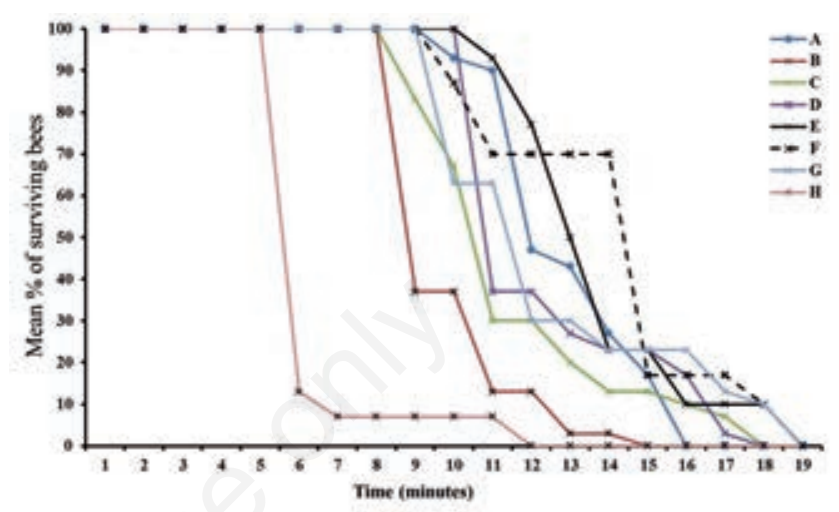

Figure 4. Decreasing the percent of surviving bees during time for different feeding choices after exposition to low temperature. (A: Liquid honey, B: Honey jelly, C: Sugar candy, D: Honey/juice jelly, E: Sugar syrup, F: Creamed honey, G: Honey candy, H: Bees without feeding).

Table 1. Means of surviving bees \pm standard error for each feeding choice at $6 \pm 1^{\circ} \mathrm{C}$ per each five minutes during the experiment $(3$ cages and 10 bees per cage for each feeding choice).

\begin{tabular}{|c|c|c|c|c|c|c|c|c|}
\hline \multirow{2}{*}{$\begin{array}{l}\text { Time* } \\
\text { (minutes) }\end{array}$} & \multirow[b]{2}{*}{$\begin{array}{l}\text { Liquid } \\
\text { honey }\end{array}$} & \multirow[b]{2}{*}{$\begin{array}{l}\text { Honey } \\
\text { jelly }\end{array}$} & \multirow[b]{2}{*}{$\begin{array}{l}\text { Sugar } \\
\text { candy }\end{array}$} & \multicolumn{2}{|c|}{ Feeding choices } & \multirow[b]{2}{*}{$\begin{array}{l}\text { Honey } \\
\text { candy }\end{array}$} & \multirow[b]{2}{*}{$\begin{array}{l}\text { Sugar } \\
\text { syrup }\end{array}$} & \multirow[b]{2}{*}{$\begin{array}{l}\text { Without } \\
\text { feeding }\end{array}$} \\
\hline & & & & $\begin{array}{l}\text { Honey/juice } \\
\text { jelly }\end{array}$ & $\begin{array}{c}\text { Creamed } \\
\text { honey }\end{array}$ & & & \\
\hline 0 to 5 & $10.0 \pm 0.0^{\mathrm{a}}$ & $10.0 \pm 0.0^{\mathrm{a}}$ & $10.0 \pm 0.0^{\mathrm{a}}$ & $10.0 \pm 0.0^{\mathrm{a}}$ & $10.0 \pm 0.0^{\mathrm{a}}$ & $10.0 \pm 0.0^{\mathrm{A}}$ & $10.0 \pm 0.0^{\mathrm{a}}$ & $10.0 \pm 0.00^{\mathrm{a}}$ \\
\hline 6 to 10 & $9.8 \pm 0.1^{\mathrm{a}}$ & $7.4 \pm 0.8^{b}$ & $9.0 \pm 0.4^{\mathrm{a}}$ & $10.0 \pm 0.0^{\mathrm{a}}$ & $9.7 \pm 0.1^{\mathrm{a}}$ & $9.2 \pm 0.4^{\mathrm{A}}$ & $10.0 \pm 0.0^{\mathrm{a}}$ & $0.8 \pm 0.2^{\mathrm{c}}$ \\
\hline 11 to 15 & $4.4 \pm 0.8^{\mathrm{ab}}$ & $0.6 \pm 0.2^{\mathrm{de}}$ & $2.1 \pm 0.5^{\mathrm{cd}}$ & $2.9 \pm 0.3^{\mathrm{bc}}$ & $5.9 \pm 0.9^{\mathrm{a}}$ & $3.4 \pm 0.5^{\mathrm{Bc}}$ & $5.3 \pm 0.9^{\mathrm{a}}$ & $0.1 \pm 0.1^{\mathrm{e}}$ \\
\hline 16 to 19 & $0.0 \pm 0.0^{b}$ & $0.0 \pm 0.0^{\mathrm{b}}$ & $0.4 \pm 0.2^{\mathrm{ab}}$ & $0.5 \pm 0.2^{\mathrm{ab}}$ & $1.0 \pm 0.3^{\mathrm{a}}$ & $1.1 \pm 0.4^{\mathrm{A}}$ & $0.7 \pm 0.2^{\mathrm{ab}}$ & $0.0 \pm 0.0^{\mathrm{b}}$ \\
\hline
\end{tabular}

${ }^{*}$ Means followed by the same letter in the same row are not significantly different according to Duncan's multiple range test 0.05 .

Table 2. The time at which bees started to recovery, means of recovered bees (showed moving ability) at $19 \pm 1^{\circ} \mathrm{C}$ after 10 and 15 minutes, and the consumption $\%$ of each feeding choice at the end of the experiment. Values are \pm standard error.

\begin{tabular}{lcccc}
\hline Feeding choice & Start to recovery (minutes) & After 10 minutes & After 15 minutes & Consumption \% \\
Liquid honey & $1.68 \pm 0.26^{\mathrm{ab}}$ & $8.33 \pm 1.20^{\mathrm{a}}$ & $8.66 \pm 1.33^{\mathrm{a}}$ & $4.66 \pm 0.66^{\mathrm{cd}}$ \\
Honey jelly & $1.55 \pm 0.33^{\mathrm{b}}$ & $6.00 \pm 0.57^{\mathrm{a}}$ & $7.33 \pm 0.33^{\mathrm{a}}$ & $2.66 \pm 0.66^{\mathrm{d}}$ \\
\hline Sugar candy & $1.71 \pm 0.2^{\mathrm{a}}$ & $9.66 \pm 0.33^{\mathrm{a}}$ & $9.66 \pm 0.33^{\mathrm{a}}$ & $9.33 \pm 0.66^{\mathrm{ab}}$ \\
Honey candy & $1.75 \pm 0.40^{\mathrm{ab}}$ & $8.00 \pm 1.52^{\mathrm{a}}$ & $8.00 \pm 1.52^{\mathrm{a}}$ & $6.66 \pm 1.33^{\mathrm{bc}}$ \\
\hline Honey/juice jelly & $2.05 \pm 0.27^{\mathrm{ab}}$ & $9.33 \pm 0.33^{\mathrm{a}}$ & $9.33 \pm 0.33^{\mathrm{a}}$ & $4.00 \pm 1.154^{\mathrm{cd}}$ \\
Creamed honey & $1.99 \pm 0.22^{\mathrm{ab}}$ & $8.66 \pm 1.33^{\mathrm{a}}$ & $8.66 \pm 1.33^{\mathrm{a}}$ & $8.66 \pm 1.33^{\mathrm{ab}}$ \\
\hline Sugar syrup & $1.50 \pm 0.27^{\mathrm{b}}$ & $6.33 \pm 2.02^{\mathrm{a}}$ & $7.66 \pm 1.45^{\mathrm{a}}$ & $11.33 \pm 1.76^{\mathrm{a}}$ \\
Without feeding & $2.58 \pm 0.01^{\mathrm{a}}$ & $0.66 \pm 0.66^{\mathrm{b}}$ & $1.66 \pm 0.33^{\mathrm{b}}$ & - \\
\hline
\end{tabular}

*Means followed by the same letter in the same column are not significantly different according to Duncan's multiple range test $t_{0.05}$. 
$11.33 \%$. Bees consumed $11.33,9.33$, and $8.66 \%$ of sugar syrup, sugar candy, and creamed honey, respectively. These feeding choices differed significantly than the rest of feeding choices. Also, bees consumed insignificantly only $6.66,4.66,4$, and $2.66 \%$ of honey candy, liquid honey, honey/juice jelly and honey jelly, respectively. The correlation between survival of bees to low temperature and consumption $\%$ was weak $(r=0.2, \mathrm{P}<0.0001)$.

\section{Survival of honey bees}

The mean percent of surviving bees differed among test groups (feeding treatments) as presented in Figure 5. Bees were able to survive from five days (unfed bees) to 24 days (bees fed on sugar candy). The impact of feeding choice on bee survival ability was significantly different $(\mathrm{df}=7, \mathrm{~F}=17.59, \mathrm{P}=0.0001<0.05)$. The approximate $\mathrm{ST}_{50}$ (the mean time at which $50 \%$ of honey bees were able to survive) ranged from three days (unfed bees) to 15.8 days (honey candy group) while $\mathrm{ST}_{0}$ (the mean time at which $0 \%$ of bees were able to survive, i.e. $100 \%$ death of the workers) ranged from 4.3 days (unfed bees) to 21.3 days (sugar candy group) as presented in Table 3. The feeding choices can be arranged in descending order according to $\mathrm{ST}_{50}$ as; honey candy, creamed honey, sugar candy, liquid honey, and sugar syrup (without significant differences among them, $\mathrm{P}>0.05$ ), followed by honey/juice jelly, honey jelly and bees without feeding. Concerning $\mathrm{ST}_{0}$, only honey jelly and unfed bees were less statistically significant than the other feeding choices as indicated in Table 3.

The correlation between percent of consumed food and workers survival period until $100 \%$ death was positive and significantly different $(\mathrm{r}=0.60, \mathrm{P}=0.0039<0.05)$. This indicates that longer survival until death is linked to the consumption of more food. From
Table 3 it is evident that bees consumed significantly more amounts of sugar syrup and liquid honey than the other feeding choices. Honey jelly was least preferred. Feeding choices in descending order according to consumed $\%$ are sugar syrup, liquid honey, honey candy, honey/juice jelly, creamed honey, sugar candy, and finally honey jelly. During the experiment, bees were observed to absorb nutrients from honey jelly without cutting it into smaller fragments (Figure 6A). In the case of honey/juice jelly, bees were able to absorb nutrients and to remove and store fragments of this feeding choice in combs (Figure 6B and C).

\section{Discussion}

\section{Preference of honey bees to specific feeding choice}

During the first three minutes, bees were attracted to all feeding choices with high preference to honey jelly, honey/juice jelly and creamed honey. This indicates that all feeding choices are desirable to starved bees and can be consumed without difficulty. During the following six and nine minutes, no bees were attracted to honey jelly or sugar syrup which indicates that these two feeding choices are not highly attractive to replete bees. At twelve or fifteen minutes, the bees seemed to be satiated and remained without feeding. After one hour, the majority of bees tended to feed on sugar candy instead of the other feeding choices. This may be explained by the high sweetness of sucrose (sugar candy) comparable to other feeding choices. According to Hough \& Phadnis (1976), sucrose has the greatest sweetness over other carbohydrates or even sucrose derivatives. Therefore, it could be expected that sugar candy (a solid form of

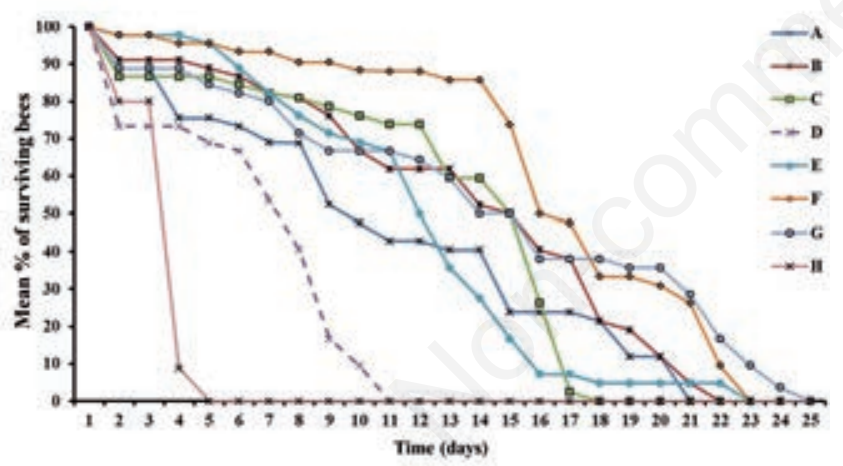

Figure 5. Decreasing mean $\%$ of surviving bees over time for different feeding choices (A: Sugar syrup, B: Liquid honey, C: Creamed honey, D: Honey jelly, E: Honey/juice jelly, F: Honey candy, G: Sugar candy, H: Bees without feed).
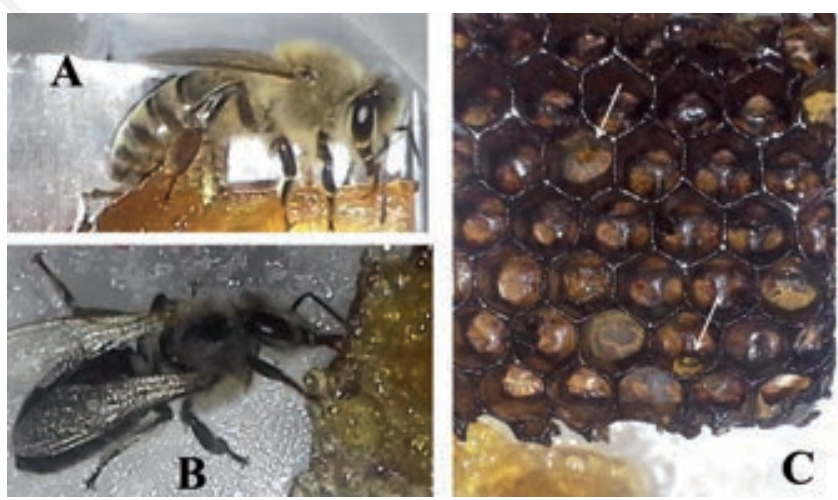

Figure 6. Worker bee is feeding on honey jelly (A). Worker bee is feeding on honey/juice jelly $(\mathrm{B})$. Workers were able to cut small pieces of the honey/juice jelly and stored them in the wax cells (jelly pieces are pointed out with white arrows) as shown in (C).

Table 3. Means \pm standard error of time (days) at which $50 \%$ of bees were able to survive $\left(\mathrm{ST}_{50}\right)$ and at which no bees were able to survive $\left(\mathrm{ST}_{0}\right)$, and consumption $\%$ of each feeding choice.

\begin{tabular}{|c|c|c|c|c|c|c|c|c|}
\hline & $\begin{array}{l}\text { Liquid } \\
\text { honey }\end{array}$ & $\begin{array}{l}\text { Honey } \\
\text { jelly }\end{array}$ & $\begin{array}{l}\text { Sugar } \\
\text { candy }\end{array}$ & $\begin{array}{c}\text { Honey/juice } \\
\text { jelly }\end{array}$ & $\begin{array}{c}\text { Creamed } \\
\text { honey }\end{array}$ & $\begin{array}{l}\text { Honey } \\
\text { candy }\end{array}$ & $\begin{array}{l}\text { Sugar } \\
\text { syrup }\end{array}$ & $\begin{array}{l}\text { Without } \\
\text { feeding }\end{array}$ \\
\hline $\mathrm{ST}_{50}$ & $13.3 \pm 2.3^{\mathrm{ab}}$ & $5.6 \pm 1.8^{c}$ & $13.3 \pm 0.3^{\mathrm{ab}}$ & $10.6 \pm 0.8^{b}$ & $14.6 \pm 0.8^{\mathrm{ab}}$ & $15.8 \pm 0.1^{\mathrm{a}}$ & $11.8 \pm 1.9^{\mathrm{ab}}$ & $3.0 \pm 0.5^{c}$ \\
\hline $\mathrm{ST}_{0}$ & $20.6 \pm 1.3^{\mathrm{a}}$ & $10.6 \pm 0.3^{b}$ & $21.3 \pm 2.7^{\mathrm{a}}$ & $18.3 \pm 2.3^{\mathrm{a}}$ & $17.0 \pm 0.5^{\mathrm{a}}$ & $21.0 \pm 1.5^{\mathrm{a}}$ & $17.6 \pm 3.3^{\mathrm{a}}$ & $4.3 \pm 0.3^{\mathrm{c}}$ \\
\hline Consumption\% & $67.0 \pm 3.2^{2 \mathrm{~b}}$ & $3.3 \pm 0.8^{\mathrm{d}}$ & $32.3 \pm 0.8^{c}$ & $43.0 \pm 3.4^{c}$ & $35.0 \pm 3.6^{\mathrm{c}}$ & $47.3 \pm 7.3^{b c}$ & $71.0 \pm 16.7^{\mathrm{a}}$ & - \\
\hline
\end{tabular}

*Means followed by the same letter in the same row are not significantly different according to Duncan's multiple range test 0.05 . 
sucrose) attracted the bees more than the other forms due to the presence of sucrose in their contents.

\section{Tolerance to low temperature}

It was apparent that feeding choices affected the ability of worker bees to tolerate low air temperatures. Honey bees require an energy source (i.e. honey or other alternative) to generate energy to cope with cold conditions. The results indicated that creamed honey, sugar syrup, honey candy or liquid honeys were better than other tested feeding choices. All of these feeding choices contained honey except sugar syrup, indicating that these feeding choices were more suitable for use as an energy source by bee workers. Although honey/juice jelly and sugar candy contains honey or sucrose they exhibited moderate ability to enhance tolerance of bees to low temperature over time. Another confirmation of the impact of feeding form is honey jelly. Bees fed on this specific feeding choice may have been unable to absorb sufficient nutrients as energy source due to its solid form. The lowest survival ability was recorded for unfed bees. The energy of these bees was expended quickly and the bees became completely motionless within 12 minutes.

It was apparent that bees fed on tested feeding choices were able to recover within 2.05 minutes. Unfed bees were slower in their recovery than fed individuals and had fewer numbers of recovered bees. This may be explained by the less energy available in unfed bees. All bees fed on tested feeding choices were able to generate sufficient energy to recover. The variations among bees in their ability to survive under cold conditions could be in part linked to the consumed percent of food. Consumption ranged from 2.66 to $11.33 \%$ with slightly higher consumption (from 8.66 to $11.33 \%$ ) of sugar syrup, sugar candy and creamed honey, respectively. Bees fed on these feeding choices also had higher survival rates. In contrast, little consumption (from 2.66 to $6.66 \%$ ) was recorded for honey candy, liquid honey, honey/juice jelly, and honey jelly, respectively. Bees fed on these feeding choices had lower survival rates than those fed on creamed honey and sugar syrup. The correlation between bees' survival to low temperature and consumption percentage was weak $(\mathrm{r}=20 \%)$. Thus, not only the consumed percent of food but also the ability of bees to utilize that food as source of energy can impact the tolerance of honey bees to low temperature.

\section{Survival of honey bees}

The results indicated that bees were able to survive for various time periods according to feeding choice. The better feeding choices, however, without statistically significant differences among them, were honey candy, creamed honey, sugar candy, liquid honey, and sugar syrup. A mixture of honey and sugar (sucrose) was most effective followed by honey only or sugar only in liquid or solid form. On the contrary, Barker \& Lehner (1978) who found that caged bees were able to survive longer when they fed on sucrose syrup than honey. In the present study, workers fed on honey survived insignificantly longer than those fed on sugar syrup. This could be explained by the variations in experiment conditions. Bees fed on sugar syrup were able to survive for at least 17.6 days. In a study by Abou-Shaara et al. (2012), hybrids of Carniolan bees at foraging age fed on sugar syrup (50\%) were able to survive only 13.67 days. The survival period recorded by AbouShaara et al. (2012) was less than the survival period of bees fed on sugar syrup as determined in the present study. This may be explained by the impact of temperature, in their study bees were kept at $35^{\circ} \mathrm{C}$ while in the present study at about $20^{\circ} \mathrm{C}$. Similarly, Remolina et al. (2007) recorded 1.2 to 3.7 days survival for worker bees exposed to $42^{\circ} \mathrm{C}$ until death. Basically, honey or sugar (sucrose) was able to provide worker bees with sufficient energy for a longer period of time than other offered feeding choices.

With respect to other tested feeding choices, honey/juice jelly performed better than honey jelly. This could be explained by the presence of sugarcane juice (source of sucrose) in honey/juice jelly as an energy source. Also, sugarcane juice in this type of jelly may increase the ability of worker bees to absorb nutrients from it over honey jelly (which has high viscosity and no sugarcane juice). Honey bees used in the experiments were able to cut fragments of honey/juice jelly and stored them in combs. This reflected the ability of bees to utilize this feeding choice over honey jelly. Bees fed on honey jelly were able to survive up to 6.3 days more than unfed bees. Due to the individual variations among tested bees, $\mathrm{ST}_{0}$ did not differ significantly among tested feedings, except honey jelly and unfed bees. It is known that hydroxymethylfurfural (HMF) is toxic substance to honey bees (Brodschneider \& Crailsheim, 2010). This substance is increased by heating honey for longer times (e.g. Sahinler \& Gul, 2005). The lowered longevity of worker bees fed on tested jellies cannot be attributed to the high HMF level because the honey was only heated in water bath for only one minute during jelly production. It is not expected that HMF levels were increased substantially to cause adverse impacts on worker bees tested. Providing bee colonies during cold air temperature with honey candy or creamed honey is suggested especially as these feeding choices showed the ability to enhance worker tolerance to cold temperatures conditions is worthy of being mentioned that the nutritional status of the colonies can not only impact the activity of bees but as well as their long-term behavioural development (Schulz et al, 1998).

The form of the feeding type (either liquid or solid) impacted the consumed amounts. It was clear the bees were able to consume significantly more amounts of liquid feedings (i.e. honey or sugar syrup). Consumption of solid feeds was correlated with the ability of worker bees to absorb nutrients. This ability was high for honey candy, honey/juice jelly, creamed honey, sugar candy, and finally honey jelly, respectively. The consumption $\%$ was moderately correlated by $60 \%$ with survival period until $100 \%$ death. However, the high consumption percent did not always indicate longer survival of workers. The utilization ability of feeding type as source of energy appears important as well.

\section{Conclusions}

The tested sugar feeding choices indicated variations in attractiveness of starved bees and to enhance the survival of bees to low air temperatures. Creamed honey, honey jelly or honey/juice jelly had high attractiveness to honey bees during the onset of experiments, but sugar candy attracted bees until the completion of experiments. Creamed honey, sugar syrup, and honey candy showed the highest ability to improve the tolerance of honey bees to cold air temperatures. During cold periods providing bee colonies with honey candy or creamed honey can be considered as suitable energy source to boost the survival of bee colonies.

\section{References}

ABD ELHAMID A.M., ABOU-SHAARA H.F., 2016 - Producing clover and cotton creamed honey under cooling conditions and potential use as feeding to honey bee colonies. - J. Apic. 31: 59-64.

ABOU-SHAARA H.F., AL-GHAMDI A.A., MOHAMED A.A., 
2012 - Tolerance of two honey bee races to various temperature and relative humidity gradients. - Env. Exp. Biol. 10: 133-138.

AL-GHAMDI A.A., ALSHARHI M.M., ABOU-SHAARA H.F., 2016 - Current status of beekeeping in the Arabian countries and urgent needs for its development inferred from a soci-economic analysis. - Asian J. Agri. Res. 10: 87-98.

ANDELKOVIĆ B., JEVTIĆ G., MLADENOVIĆ M., PETROVIĆ M., VASIĆ T., 2011 -Influence of spring feed on the strength of honey bee colonies during spring development. Biotechnol. Anim. Husb. 27: 1757-1760.

BAILEY L., 1966 - The effect of acid-hydrolysed sucrose on honeybees. - J. Apic. Res. 5: 127-136.

BARKER R.J., 1977 - Some carbohydrates found in pollen and pollen substitutes are toxic to honey bees. - J. Nutr. 107: 18591862.

BARKER R.J., LEHNER Y., 1978 - Laboratory comparison of high fructose corn syrup, grape syrup, honey, and sucrose syrup as maintenance food for caged honey bees. - Apidologie 9: 111-116.

BRODSCHNEIDER R., CRAILSHEIM K., 2010 - Nutrition and health in honey bees. -Apidologie 41: 278-294.

BRODSCHNEIDER R., MOOSBECKHOFER R., CRAILSHEIM K., 2010 - Surveys as a tool to record winter losses of honey bee colonies: a two year case study in Austria and South Tyrol. - J. Apic. Res. 49: 23-30.

CARRILLO M.P., KADRI S.M., VEIGA N., ORSI R.D.O., 2015 Energetic feedings influence beeswax production by Apis mellifera L. honeybees. - Acta Scient. 37: 73-76.

GENERSCH E., OHE W.V.D., KAATZ H. SCHROEDER A., OTTEN C., BUCHLER R., BERG S., RITTER W., MUHLEN W., GISDER S., MEIXNER M., LIEBIG G., ROSENKRANZ P., 2010 - The German bee monitoring project: a long term study to understand periodically high winter losses of honey bee colonies. - Apidologie 41: 332-352.

HOUGH L., PHADNIS S.P., 1976 - Enhancement in the sweetness of sucrose. - Nature 263: 800.

KLEINHENZ M., BUJOK B., FUCHS S., TAUTZ J., 2003 - Hot bees in empty broodnest cells: heating from within. - J. Exp. Biol. 206: 4217-4231.

NGUYEN B.K., MIGNON J., LAGET D., DE GRAAF D., JACOBS F.J., VANENGELSDORP D., BROSTAUX Y., SAEGERMAN C., HAUBRUGE E., 2010. - Honey bee colony losses in Belgium during the 2008-9 winter. - J. Apic. Res. 49: 337-339.

REMOLINA S.C., HAFEZ D.M., ROBINSON G.E., HUGHES K.A., 2007 - Senescence in the worker honey bee Apis mellifera. - J. Insect Physiol. 53: 1027-1033.

SAHINLER N., GUL A., 2005 - Effect of heating and storage on honey hydroxy methylfurfural and diastase activity. - J. Food Technol. 3: 152-157.

SCHULZ D.J., HUANG Z.Y., ROBINSON G.E., 1998 - Effects of colony food shortage on behavioral development in honey bees. - Behav. Ecol. Sociobiol. 42: 295-303.

SEELEY T.D., VISSCHER P.K., 1985 - Survival of honeybees in cold climates: the critical timing of colony growth and reproduction. - Ecol. Entomol. 10: 81-88.

SIMPSON J., 1964 - Dilution by honeybees of solid and liquid food containing sugar. - J. Apic. Res. 3: 37-40.

SOUTHWICK E.E., HELDMAIER G., 1987 - Temperature control in honey bee colonies. - BioSci. 37: 395-399.

SPLEEN A.M., LENGERICH E.J., RENNICH K., CARON D., ROSE R., PETTIS J.S., HENSON M., WILKES J.T., WILSON M., STITZINGER J., LEE K., ANDREE M., SNYDER R., VANENGELSDORP D., 2013 - A national survey of managed honey bee 2011-12 winter colony losses in the United States: results from the bee informed partnership. - J. Apic. Res. 52: 44-53.

VANENGELSDORP D., HAYES J., UNDERWOOD R.M., PETTIS J., 2008 - A survey of Honey Bee colony losses in the U.S., Fall 2007 to Spring 2008. - PLoS ONE 3: e4071.

WANG Y., CAMPBELL J.B., KAFTANOGLU O., PAGE JR R.E., AMDAM G.V., HARRISON J.F., 2016 - Larval starvation improves metabolic response to adult starvation in honey bees (Apis mellifera L.). - J. Exp. Biol. 219: 960-968. 